Kong. Res. J. 1(1) : 4-6, 2014

Kongunadu Arts and Science College, Coimbatore

\title{
FROM SUBSERVIENCE TO SELF-ASSERTION: TRANSFORMING FEMALE IDENTITY IN AMY TAN'S THE KITCHEN GOD'S WIFE
}

\author{
Shobha Ramaswamy+ \\ Department of English, Kongunadu Arts and Science College, Coimbtore-641 029. \\ *Email: ramaswamy.shobha@gmail.com
}

\begin{abstract}
Amy Tan, the well-known Chinese American author has won acclaim for her depiction of various aspects of the mother-daughter relationship and the depiction of the female struggle against patriarchal society. The Kitchen God's Wife is the story of Winnie Louie, a Chinese immigrant, as told to her Americanborn dentist daughter, Pearl. Weili, as Winnie is known in China, is the victim of an abusive marriage. She is the wife of the cruel Wen Fu, whom she later mentally renames "The Kitchen God" Weili endures considerable physical, mental and emotional torture with passivity because she the ideal of the subservient Chinese wife has been inculcated in her. Weili's perspective opens up when she meets Jimmy Louie, a Chinese American soldier. He gives her a new, Western name, that of "Winnie," and paves a way for her search for an identity apart from her husband. Winnie has to face a series of horrendous trials before she marries Jimmy and settles in the United States. After Jimmy's death, Winnie forges out a new, independent life for herself. She gives her daughter the courage to overcome her illness by fashioning a new goddess from a defective statuette. Winnie names this symbolic recreation of her own self as "The Kitchen God's Wife." From victim, she becomes a victor, capable of nurturing and protecting her progeny.
\end{abstract}

Keywords: Amy Tan, Kitchen god's wife.

The Kitchen God's Wife has been described as "an extremely complex postmodern literary novel" (Endnotes.com). Amy Tan's book, with its strong autobiographical note depicts life in old China as well as the immigrant and second-generation Chinese American experience. It begins with the narrative of Pearl Louie Brandt, a typical secondgeneration Chinese American woman married to a white American. She visits her mother widowed mother, Winnie Louie, from whom she has been estranged for a number of years. During the visit, Winnie relates the story of her past in preCommunist China. She also tells Pearl that she is not the daughter of Jimmy Louie, the gentle Baptist pastor who passed away when Pearl was a teenager, but that of Winnie's first husband, a wicked man named Wen Fu. This narration creates a closer understanding between mother and daughter and also paves the way for Winnie to come to terms with herself.

Winnie, whose Chinese name is Jang Weili, is brought up in strict accordance with the ideology of Confucius which relegates women to a secondary position in society. In the words of Judith Caesar, "The Kitchen God's Wife acknowledges the historical role played by patriarchal ideology in its moulding of Chinese women." Women in China were trained to be gentle and submissive, with the pleasing of their husbands as their main aim in life. Women like
Weili's mother, who was an educated "Shangai woman" were ostracized by society.

Weili is given in marriage to the attractive but greedy and wicked Wen Fu. Her innocence is exploited by her husband, who makes her a slave to his whims and fancies. He claims absolute mastery over her body and mind ("Character"). He proves to be dangerously jealous and cruel. He crushes Weili's self-esteem by insulting her in public, making her suffer untold miseries in private, demanding that she beg and fawn on the ground for imaginary slights. Wen Fu and his family shamelessly spend her dowry and try ways and means to take advantage of her father's wealth and position. Weili loses several children due to Wen Fu. Particularly pathetic is the death of Yiku. She becomes retarded after being hit by her father who wants to punish Weili. While the little girl lies seriously ill, Wen Fu plays cards and refuses to take her to a doctor until it is too late. After a point of time, Weili begins to abort the life in her womb to save her offspring from the unhappy life she foresees for them. It is to be noted that Wen Fu treats his concubines and his other women in an equally atrocious manner. Weili speaks of her huaband's ill-treatment: "I was not angry. I did not know I was supposed to be angry. This was China. A woman had no right to be angry" (Tan 170).

Weili's life begins to change when she meets Jimmie Louie, and American-born Chinese soldier 
during the war. Jimmie gives her a new name, 'Winnie,' echoing the word 'win.' This renaming is the beginning of a new life for her. After a few years, she makes the brave decision to break away from her abusive marriage. She is heartened to do so when she learns of her cousin Peanut's escape from her mentally-retarded husband. She also visits the shelter that the mother of one of her classmates runs for women who wish to leave unbearable marriages. She is delayed by the legal action that Wen Fu takes against her. It is the patriarchal system that enables Wen Fu to exploit powerful institutions such as the law and media to represent himself as having lost his son, wife and property. Winnie is prepared to go to jail rather than continue as the subservient wife of a heartless man. In prison, she is considered a heroine by some and by others, an immoral and heartless woman who lets her son die in order to enjoy the love of a foreigner. However, Winnie retains the true devotion of the pure-hearted Jimmie Louie, who arranges for her emigration to the United States as his wife.

After her release, Winnie is determined to legalise her marriage to Jimmie by getting a proper divorce from Wen Fu. Even though her tickets are ready and she is has been acknowledged as the wife of Jimmie in the United States, her stubborn nature refuses to settle for nothing less than the truth. She formulates a plan with the help of her friend Helen and Wan Betty the telegraph operator to publicly force Wen Fu to retract his lies about not divorcing her previously. She makes him sign another divorce paper. However, Wen $\mathrm{Fu}$ has his revenge. He gains entry into her home, rapes her at gunpoint and makes her beg him for her air tickets. Winnie manages to get hold of the gun and would have shot him but for the timely intervention of Helen. She escapes to the United States, but only with Wen Fu's child in her womb. Winnie is able to begin her life again in spite of the trauma she faces. She brings up her daughter Pearl and the son she has later. After Jimmie's early death, she leads an independent life. This continues even in her old age. Things come to a head when Pearl reveals to her that she is suffering from multiple sclerosis, an incurable condition.

The title of the novel is based on the legend of the Kitchen God. In Chinese folklore, he was a man named Zhang who was married to a wonderful lady named Guo, who had all the virtues expected of a typical traditional Chinese wife. Zhang lacked nothing in life, but suffered from the malaise of discontent. He acquires a mistress called Lady Li. Zhang starts ill-treating his wife and finally throws her out of his house. As fate would have it, Lady Li proves faithless and leaves him for another man.
Zhang is reduced to the condition of a beggar. A kindly woman offers him food and shelter. To his shock and dismay, Zhang finds one day that his benefactress is his own wife. Unable to face what seems to his ego a disgrace, he commits suicide by throwing himself into the fireplace in the kitchen. In a rather puzzling manner, he is elevated to the status of the Kitchen God with the power to tell the Jade Emperor of heaven who deserved reward and who punishments. The fate of his guiltless wife Guo is obscure, no particular reward coming to her share for her charitable and forgiving nature. This reflects the injustices in the traditional Chinese society, where women are expected to be subservient at all times to the male ego.

The Kitchen God is supposed to be a capricious dictator, one who expects to be pleased and served unquestioningly, and whose patriarchal superiority is unshakeable. He reminds Winnie of Wen Fu and the way he expected her to grovel before him in order to appease uncontrollable anger. "Winnie does not feel that the Kitchen God is worth honoring" ("Mythology"). She feels that "His wife is the good one not him" (Tan 12).Winnie decides that such a cruel god with his whims and fancies would not bring her daughter the kind of luck she needed. Therefore, she throws the picture of Zhang into the fire, setting off the fire alarm in the process. This incongruous intrusion of the modern, Western sound at this conjecture is momentarily misinterpreted by Winnie as Wen Fu's angry cry. She soon realizes the delusion created by her deeply-ingrained fear and feels relief. She remembers that the wicked god as well as her tyrannical husband is dead.

Winnie's mind is set upon finding an appropriate statuette to take the place of the now defunct Kitchen God. She rejects several deities shown to her at the shop and instead, chooses a small statuette which has a defect. There is no name written on its pedestal. Winnie's imagination is heightened by the possibility of creating a new goddess to give her daughter the new kind of luck to see her through her new, American-style illness. She writes in gold paint the name of the new goddessLady Sorrowfree. This is perhaps a reflection of the name she gives her stillborn baby girl, Mouchou, which also means "sorrowfree." Winnie felt that all female children were born for grief, and that her little girl had escaped her fate. Thus, she consoled herself for the loss of her child, which she superstitiously attributed to the dropping of a pair of scissors.

When Winnie lost her child in China, she was a helpless housewife, having no control over her 
body, mind or fortunes. Therefore, she was unable to offer protection to any of her children. Now, she was an American citizen, a lady making her own living, leading an independent life, well aware of her rights. As a mother, she had the freedom and the capacity to save her daughter Pearl from the fate of her children born in China. As a typical Chinese housewife, she had no right to any choice. She was not appreciated for any of her sacrifices. In a way, she was similar to Guo, the Kitchen God's wife. Feeling the need for recognition and empowerment, Winnie identifies herself with Guo and elevates the lady to the status of a deity, Lady Sorrowfree. She gives the goddess an altar, making her quite independent of her husband. It is noteworthy that the new goddess occupies the place of the Kitchen God, and is portrayed as laughing and crying out "Yes, yes, yes!"(Tan 413) in approval when he perishes in the fire. This reflects Winnie's fantasies of Wen Fu's death during his service as a pilot during the war. These wishes of Winnie are wicked but merely the feelings of a desperate animal caged and ill-treated beyond endurance, and that of a mother forced to witness the death of her children due to callous neglect.

The newly-created mother goddess is Winnie herself, who knows instinctively the kind of luck that Pearl needs. She has a deep-seated feeling that the multiple sclerosis that her daughter suffers from is the inheritance of her father. As the first step towards freeing her daughter from his evil influence, she has exorcised his memory by destroying the picture of the Kitchen God. As a second step, she creates a positive flow of energy by installing a new deity. The male here is identified with the negative and the female with the positive, which is an inversion of the yin-yang theory of Chinese philosophy. This in itself is an assertion of the feministic viewpoint that Winnie acquires upon her migration to the United States.

Winnie also takes a third and more tangible step in the form of a proposed journey to China to treat her daughter with the life-giving water of the spring in and consult traditional Chinese herbal doctors. She is purged of many sorrows. She had secret fears about Wen Fu getting to know about Pearl's existence, guessing that she was his daughter and coming to claim her. She is persuaded by Helen to reveal to Pearl the truth about her past. Winnie also finds that both Helen and Auntie Du knew all along that Pearl was not Jimmie Louie's child. Nevertheless, they approved of her deception. All this proves a relief to Winnie. She finally gets the support of the only family she has now. The news of
Wen Fu's death, sent by Wan Betty soothes her fears. She feels that now she is Lady Sorrowfree, a recreated being. She is not one who has never known any sorrow, but one who overcomes all sorrows and emerges triumphant. Winnie comes into terms with herself, redefines herself, and becomes a divine being, a fully-realised mother.

Winnie gains the confidence that she could fight and win the battle of illness on behalf of her daughter. The effort, after all, is similar to her heroic struggle to escape from Wen Fu. Thus, from the frail lady Jang Weili emerges the formidable matriarch Winnie Louie, filled with the wisdom to lead, the ability to bless with luck and the foresight and fortitude to change adversity into good fortune. As Adams puts it, Lady Sorrowfree has "endured all, received no credit for the work she has done, and is still strong

\section{REFERENCES}

Adams, B. (2011). Representing History in Amy Tan's Kitchen God's Wife

Melus, (2003). "Haunted History" (Summer 2003): 930. Annaina's Amy Tan Page. Jstor.org.,Web. 7 Mar. 2011.

Caesar, Judith. (1994-95). Patriarchy, Imperialism and Knowledge in The Kitchen God's Wife. North Dakota Quarterly 62.4: 164-74. Print.

Character Analysis of Wen Fu in The Kitchen God's Wife. Endnotes.com. Web. 9 Mar (2011).

The Kitchen God's Wife. Endnotes.com, 2009. Web. 11 Mar (2011).

Ling, Amy. Between Worlds: Women Writers of Chinese Ancestry. New York: Pergamon, (1990). Print.

Mythology, Luck and Fate in The Kitchen God's Wife and The Bingo Palace. 123 Helpme.com. 9 Mar.2011.

Tan, Amy. The Kitchen God's Wife. New York: Vintage Contemporaries, (1991). Print.

Wong, Sau-ling Cynthia. Sugar Sisterhood: Situating the Amy tan Phenomenon. The Ethnic Canon: Histories, Institutions, and Interventions. Ed. David Palumbo-Liu. Minneapolis. Minnesota UP, (1995). 174-210. Print. 